\title{
Users' Reactions to CD-ROM: The Penn State Experience
}

\section{Cindy Faries}

Currently, many academic libraries own CD-ROM systems. Using a self-designed questionnaire, this study surveyed users of CD-ROMs for two two-week periods in the fall of 1989 and the spring of 1990 . The results provided valuable information about who was using the systems; which systems were the most popular; how patrons perceived help available to them; what type of instruction they would desire; and what suggestions patrons had to offer to improve service to this technology. As academic libraries increasingly adopt new technologies, user surveys such as this one will provide important information to librarians about implementing services and procedures.

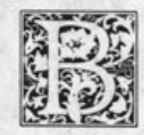

y now, bibliographic and fulltext databases on CD-ROM are a well-established facet of many academic libraries. In 1986, articles began appearing in Library Literature discussing the emerging technology of CD-ROMs and how libraries were beginning to use this technology. ${ }^{1}$ Within two to three years, academic libraries began to report on studies or evaluations of patrons' responses to these CD-ROM systems. Most patrons were excited about these new products, but they did need some assistance using them. At the Pennsylvania State University, an evaluation of the CD-ROM area was conducted on two separate occasions: for a two-week period in September 1989 and for a two-week period in April 1990. The study was conducted in the General Reference Section of Pattee Library for two reasons: (1) this area was the first to introduce $\mathrm{CD}-\mathrm{ROM}$ products into the Penn State Libraries and (2) General Reference has the largest num- ber of CD-ROM systems in the library. This area, thus, had a large population of users who had been exposed to this new technology for a few years.

The purpose of the study was to determine how users were reacting to this new electronic reference area. The results would allow the section to improve service for these new reference tools and to be able to plan for future technological developments. A questionnaire and informal observation of patron behavior were used to gather information about users' reactions to the CD-ROMs. Because Penn State was one of the first academic libraries to install several CDROM products, the experiences and satisfaction of its clientele should prove valuable to other academic libraries as they implement CD-ROMs and more advanced technological resources.

\section{REVIEW OF THE LITERATURE}

Many, many articles have appeared in the literature in the past few years de-

Cindy Faries is Reference Librarian and Automation Coordinator in the General Reference Section of Pattee Library, Pennsylvania State University, University Park, Pennsylvania 16802. The author wishes to thank Susan Day, former Reference Technology Assistant, for her assistance in compiling and tabulating the data from this survey. Readers may contact the author for copies of the survey. 
scribing users' reactions to CD-ROM products in a variety of libraries. Some of these articles deal with major evaluations of optical products both in the United States and abroad. Caroline Moore surveyed libraries using CDROM products in the United Kingdom while Jenny Stocks did a similar study of academic and special libraries using CDROMs in Australia. ${ }^{2}$ Ching-chih Chen and David Raitt have written extensively on the use of CD-ROMs in a variety of libraries in the United States and Western Europe, and Barbara A. Rapp and others have written on the National Library of Medicine's field test of sites with MEDLINE on CD-ROM. ${ }^{3 .}$ User studies limited to special libraries also exist. Most of these, including studies by Anchalee Chamchuklin and Aung-Myint, Beryl Glitz, Maureen Wong and others, and Peter M. LePoer and Carol A. Mularski discuss the use of MEDLINE in both U.S. and foreign university medical libraries. ${ }^{5}$ L. Scott Rawnsley surveyed CD-ROM users in a law library and John J. Welsh reported on CD-ROM use in a government research library. ${ }^{6}$ Carolyn Pope and Jean Reese have published separate studies of the use of CD-ROMs in university education libraries. ${ }^{7}$ Finally, Sten Wiksten even reported on a Swedish public library's experience with CD-ROMs. ${ }^{8}$

Nonetheless, the largest number of articles describing users' reactions to CDROM are from university or academic libraries. Most of these articles are generic, describing general patron and sometimes staff reactions to a variety of CD-ROM products and services in university libraries. ${ }^{9}$ Other articles examine experiences patrons have had using just one product. ${ }^{10}$ Some articles also compare products, mostly WILSONDISC and InfoTrac, in university settings," while Carol Reese compared the use of a manual index versus a CD-ROM index. ${ }^{12}$ Gillian Allen has written about the types of CD-ROM training university students want and the appropriateness of database selection by university students using CDROM products. ${ }^{13}$ Finally, Susan K. Charles and Katherine E. Clark have written about updating CD-ROM searching with online searching. ${ }^{14}$

\section{BACKGROUND}

In 1986, Pattee Library acquired InfoTrac, which was placed in the General Reference Section serving faculty, staff, graduate, and undergraduate students in business, the social sciences, and all the humanities except art and music. As the name implies, the section also handles many questions of a general nature from its primary clientele and also from other users who are not affiliated with the university. ERIC and Compact Disclosure arrived soon after InfoTrac. InfoTrac was canceled in the summer of 1988 because of repeated equipment failures and an inadequate response to this problem by the vendor. The resultant savings enabled the library to purchase six other products and to create the General Reference Section CD-ROM Area which currently consists of eleven products running on ten workstations. The eleven products include Readers' Guide, Business Periodicals Index, Social Sciences Index, Humanities Index, and the MLA Bibliography from Wilson; ERIC, PsycLIT, and SPORT Discus from Silver Platter; $\mathrm{ABI} /$ Inform and Dissertation Abstracts International from University Microfilms; and Compact Disclosure from Disclosure. The Humanities Index and the MLAsharea workstation. Allother products stand alone. A twelfth product, the Oxford English Dictionary (OED) from Tri Star, is made available to patrons only by special appointment because of its unique searching features.

When the CD-ROM area was set up, a separate service desk was established to handle CD-ROM questions because of heavy traffic at the reference desk. Staff in the reference section also work at this desk a few hours per week so that the CD-ROM desk coverage averages about 45 hours each week. Each workstation is equipped with instruction sheets, search strategy worksheets, and a thesaurus if available.All systems except ERIC, PsycLIT, and SPORT Discus have a first-come, first-served sign-up sheet allowing patrons thirty minutes to search. At the 
three Silver Platter workstations, signup sheets are put out for two weeks, and patrons can sign up for two hours per week limited to one hour per day in onehalf-hour slots. Bruce Bonta and Sally Kalin's article, "CD-ROM Implementation: A Reference Staff Takes Charge," provides a full description of the implementation and layout. ${ }^{15}$

\section{PROBLEM TO BE STUDIED}

The CD-ROM area maintained this configuration nearly one year. As the librarians in the section grappled with various problems ranging from routine maintenance of machinery to educating users, several questions began to arise:

1. Who are the majority of users?

2. Which systems are the most popular, and are patrons using the appropriate systems for their needs?

3. How do patrons perceive the help available to them?

4. How long do patrons search, what results do they get, and are they happy with these results?

5. Are patrons using CD-ROMs to the exclusion of traditional print sources?

6. Finally, what suggestions can patrons offer to help improve the CDROM service area?

Several librarians in the section had formed impressions concerning the answers to some of these questions, and for other questions estimates could be made. However, as the Penn State Libraries began to add additional CDROM titles and to plan for other technologies such as loading databases on its online catalog, LIAS, more accurate answers and better knowledge of the user community were needed. Other studies of CD-ROM end-users have either (a) been very broad, looking at several libraries' initial impressions of CD-ROM products, (b) focused on a specific category of users, e.g., patrons in a law or education library, or (c) compared use of two or more products by library patrons. To date, no study of the user community in a busy university library reference area has been conducted. Answers to local questions, such as which systems are preferred by under- graduates and graduate students, or whether or not one group would like a class teaching CD-ROM use, or how well the various groups understand instruction sheets, can help other libraries of similar size and organization plan for better delivery of electronic resources.

\section{METHODOLOGY}

To answer some of these questions and to see how patrons were responding to this new technology in the library, a questionnaire was designed and handed out for two two-week periods in September 1989 and April 1990. SPORT Discus was on trial from the vendor and the OED was excluded because it is available only by appointment. The population studied were users of the General Reference Section in Pattee Library. The sample population consisted of those users who appeared at our CD-ROM area for the periods in which the survey was handed out. The survey was originally designed by the author to determine characteristics of the user community and their impressions of these systems to aid in a conference presentation in the fall of 1989. The survey employed multiple choice, dichotomous scale, Likert scale, and one open-ended question. The author studied surveys of CD-ROM use from other academic libraries and received feedback from five colleagues, but because of time constraints no pretest of the survey was carried out in the fall semester. As the spring semester began, the author wished to sample users again, but this time at the end of a semester. Certain questions were revised to make them less ambiguous and one additional question was added. Again, no pretest was carried out.

Ideally, questionnaires should be designed with precision and administered to obtain the most accurate results. Since this questionnaire was not pretested, and some questions were altered for the spring survey, the results cannot prove or disprove any initial hypotheses the author or her colleagues had. Time was a critical factor in getting the survey done, and the Reference Section was most interested in quantitative data con- 
March 1992

cerning the user community. Therefore, while the data from the survey must be looked at with some skepticism, the data has provided the Reference Section with many explanations about the user community at Penn State and how we can best serve this community as we move to other technology initiatives.

\section{THE RESULTS}

Approximately 300 questionnaires were given out during each two-week period. Two hundred and sixty-nine (90\%) surveys were returned in the fall, and $266(89 \%)$ surveys were returned in the spring for a total of 535 . The results from the surveys were analyzed using the IBM package Reflex, which combines features of a spread sheet and database manager. Reflex does not offer built-in statistical tests; however, for the purpose of basic descriptive statistical computations, it can be quite powerful. With its cross-tabs view, Reflex can create frequency tables for single variables.

The findings from the questionnaires helped to prove many assumptions held by librarians in the section. Table 1 shows results of the status of users.

Juniors and seniors were by far the heaviest group of users, almost $56 \%$, followed by master's students, doctoral students, and then freshmen and sophomores. The table also shows percentage of use by faculty, staff, and other, but since only six surveys were returned by faculty, four by staff, and 16 by patrons marking other, few conclusions can be drawn from these groups. It is valuable to know that so few faculty and staff use the systems, but this had been the impression of the librarians in the section.

Table 2 shows percentages of users by college. Overall, the heaviest group of users came from the College of Liberal Arts, followed by the College of Business Administration and then the College of Health and Human Development. At first it seemed strange that so many users came from the College of Liberal Arts, but this college is the second largest on campus encompassing over 35 majors and 10 minors. The second and third largest groups of users were no surprise,
TABLE 1

\begin{tabular}{lc}
\multicolumn{2}{c}{ STATUS OF USERS AT PENN STATE } \\
\hline
\end{tabular}

TABLE 2

STATUS OF USERS BY COLLEGE OR DEPARTMENT (TOTAL FOR BOTH SEMESTERS)

\begin{tabular}{lr}
\hline & $\begin{array}{r}\text { Total } \\
\%\end{array}$ \\
\hline Agriculture & 1.7 \\
Art & .8 \\
College of Business & 21.1 \\
$\quad$ Administration & \\
Communications & 9.7 \\
$\begin{array}{l}\text { Department of } \\
\text { Undergraduate Studies }\end{array}$ & .9 \\
Education & 11.4 \\
Earth and mineral sciences & .6 \\
$\begin{array}{l}\text { Engineering } \\
\text { Health and human } \\
\text { development }\end{array}$ & 2.6 \\
Liberal arts & 15.7 \\
Science & 29.3 \\
\hline
\end{tabular}

since the Colleges of Business Administration and Health and Human Development have several courses requiring library research. Students from these two colleges have traditionally used the library, and the Reference Section often works with these groups in bibliographic instruction sessions.

Table 3 shows the breakdown of users by both college and class status. Among the most frequent group of users, juniors and seniors, the largest percentage came from liberal arts followed by large percentages from business administration and health and human development. 
TABLE 3

STATUS OF USERS BY CLASS AND COLLEGE

\begin{tabular}{lcccc}
\hline & $\begin{array}{c}\text { Doctoral } \\
\text { Students (\%) }\end{array}$ & $\begin{array}{c}\text { Master's } \\
\text { Students (\%) }\end{array}$ & $\begin{array}{c}\text { Juniors and } \\
\text { Seniors (\%) }\end{array}$ & $\begin{array}{c}\text { Freshmen and } \\
\text { Sophomores (\%) }\end{array}$ \\
\hline Agriculture & 0.0 & 0.4 & 0.7 & 0.6 \\
Art & 0.0 & 0.0 & 0.6 & 0.2 \\
College of Business Administration & 0.6 & 7.8 & 11.2 & 1.1 \\
Communications & 0.0 & 0.2 & 8.0 & 1.3 \\
Division of Undergraduate & & & & \\
$\quad$ Studies & 0.0 & 0.0 & 0.0 & 0.9 \\
Education & 2.6 & 3.2 & 3.2 & 1.5 \\
Earth and mineral science & 0.0 & 0.0 & 0.4 & 0.2 \\
Engineering & 0.2 & 0.3 & 0.9 & 1.1 \\
Health and human development & 0.7 & 2.2 & 11.2 & 0.7 \\
Liberal arts & 5.0 & 4.7 & 17.9 & 1.3 \\
\hline
\end{tabular}

Among master's students, the largest percentage came from business administration. This figure correlates with librarians' impressions and the fact that this college is growing in number and prestige. For doctoral students, only $10 \%$ of the total respondents, most users came from the Colleges of Liberal Arts and Education. For freshmen and sophomores, also only $10 \%$ of the total, users were spread out between business administration, communications, education, engineering, and liberal arts.

To date, no study of the user community in a busy university library reference area has been conducted.

None of these figures was too surprising, yet they do not reveal a complete picture. The Reference Section was also very interested in which CD-ROMs were the most popular. By observation and study of the sign-up sheets, the section had drawn conclusions about which systems were the most popular, and for the most part, the results of the survey verified these subjective impressions. Table 4 shows the most popular databases overall and by class.

Overall, the most popular databases were Readers' Guide, Social Sciences Index, and Business Periodicals Index. By class, doctoral and master's students used ERIC, PsycLIT, DAI, and the MLA Bibliography more than other groups; juniors and seniors favored all the business systems as well as Readers' Guide and Social Sciences Index; and freshmen and sophomores preferred Readers' Guide and Social Sciences Index. These figures offer few surprises as well. The Readers' Guide, Social Sciences Index, and Business Periodicals Index should be the most popular CD-ROMs in a humanities and social sciences reference area serving a large number of undergraduates. Furthermore, one would expect graduate students to use more sophisticated and research-oriented databases such as the MLA, DAI, or ERIC. Unsurprisingly, upper-level undergraduates favored the business systems. Besides the upper-level classes taught in the College of Business Administration itself, other departments offer courses in which students use these systems. Most notable are two difficult research courses in the hotel, restaurant, and institutional management program and business writing, one of four choices for a required writing course. Students generally enroll in these courses in their third or fourth years. Happily, the match 
TABLE 4

MOST POPULAR CD-ROMS (OVERALL AND BY CLASS)

\begin{tabular}{|c|c|c|c|c|c|c|c|c|c|c|}
\hline & $\begin{array}{c}\text { RDG } \\
(\%)\end{array}$ & $\begin{array}{l}\text { SSI } \\
(\%)\end{array}$ & $\begin{array}{l}\text { BPI } \\
(\%)\end{array}$ & $\begin{array}{c}\text { PSYC } \\
(\%)\end{array}$ & $\begin{array}{c}\text { ERIC } \\
(\%)\end{array}$ & $\begin{array}{l}\mathrm{ABI} \\
(\%)\end{array}$ & $\begin{array}{c}\text { COMP } \\
\text { DISC } \\
(\%)\end{array}$ & $\begin{array}{c}\text { HUM } \\
(\%)\end{array}$ & $\begin{array}{l}\text { DAI } \\
(\%)\end{array}$ & $\begin{array}{c}\text { MLA } \\
(\%)\end{array}$ \\
\hline Overall & 22.1 & 22.1 & 20.7 & 18.1 & 16.1 & 13.6 & 12.2 & 8.8 & 8.2 & 5.2 \\
\hline $\begin{array}{l}\text { Doctoral } \\
\text { students }\end{array}$ & 2.0 & 7.9 & 3.9 & 49.0 & 33.3 & 5.9 & 3.9 & 7.8 & 17.6 & 15.7 \\
\hline $\begin{array}{l}\text { Master's } \\
\text { students }\end{array}$ & 12.8 & 14.7 & 23.8 & 13.8 & 26.6 & 20.2 & 16.5 & 10.1 & 15.6 & 11.0 \\
\hline $\begin{array}{l}\text { Juniors and } \\
\text { seniors }\end{array}$ & 25.5 & 27.5 & 25.5 & 14.4 & 8.0 & 14.4 & 13.7 & 9.1 & 4.4 & 27.2 \\
\hline $\begin{array}{l}\text { Freshmen } \\
\text { and } \\
\text { sophomores }\end{array}$ & 43.1 & 17.6 & 5.9 & 9.8 & 11.1 & 7.8 & 3.9 & 9.8 & 5.9 & 17.6 \\
\hline
\end{tabular}

TABLE 5

USERS' REACTIONS TO INSTRUCTION SHEETS (OVERALL AND BY CLASS)

\begin{tabular}{lccccc}
\hline & $\begin{array}{c}\text { Very } \\
\text { Helpful }(\%)\end{array}$ & $\begin{array}{c}\text { Moderately } \\
\text { Helpful }(\%)\end{array}$ & $\begin{array}{c}\text { Slightly } \\
\text { Helpful }(\%)\end{array}$ & $\begin{array}{c}\text { Not at All } \\
\text { Helpful }(\%)\end{array}$ & $\begin{array}{c}\text { Did Not Use } \\
(\%)\end{array}$ \\
\hline Overall & 38.7 & 38.5 & 12.3 & 1.1 & 8.6 \\
Doctoral students & 45.1 & 43.1 & 5.9 & 0.0 & 5.9 \\
$\begin{array}{l}\text { Master's students } \\
\text { Juniors and seniors }\end{array}$ & 39.5 & 38.5 & 11.0 & .9 & 10.1 \\
$\begin{array}{l}\text { Freshmen and } \\
\text { sophomores }\end{array}$ & 38.6 & 36.6 & 13.1 & .7 & 9.7 \\
\hline
\end{tabular}

between most popular databases and a patron's class status shows that users are at least making a wise choice about which databases may be most useful for their purposes.

Although patrons may initially choose a suitable CD-ROM for their needs, many will have questions. A series of questions on the survey (numbers 4-6 on the fall survey and numbers 5-7 on the spring survey) attempted to gather reactions about patrons' perceptions of the help available to them. Table 5 reveals users' reactions to the printed instruction sheets, overall and by class status.

Over $70 \%$ of the users found the instructions to be very or moderately helpful, and only slightly over $1 \%$ did not find the instructions useful. By class status, nearly all groups found the instruction sheets useful, with doctoral students and freshmen and sophomores registering the highest rate of satisfaction. While only $9 \%$ of all users did not use the instruction sheets, most of these tended to be either master's students or juniors and seniors. On the question of whether a patron asked a library employee for help, table 6 shows a nearly even split among those patrons who did or did not ask for help.

Graduate students asked for help more often than the undergraduate user. Knowing this, the Reference Section staff can try to make a more concerted effort

TABLE 6

USERS WHO ASKED FOR HELP

\begin{tabular}{lrr}
\hline & Yes (\%) & No (\%) \\
\hline Doctoral students & 4.8 & 4.7 \\
Master's students & 10.8 & 9.3 \\
Juniors and seniors & 23.2 & 32.3 \\
Freshmen and sophomores & 3.0 & 1.9 \\
Total & 46.5 & 52.9 \\
\hline
\end{tabular}


TABLE 7

TIME SEARCHES TOOK BY CLASS (TOTAL FOR SEMESTERS)

\begin{tabular}{lcccc}
\hline \hline & \multicolumn{4}{c}{ Percentage } \\
\cline { 2 - 5 } & $\begin{array}{c}5-15 \text { Minutes } \\
(\%)\end{array}$ & $\begin{array}{c}15-30 \text { Minutes } \\
(\%)\end{array}$ & $\begin{array}{c}30-60 \text { Minutes } \\
(\%)\end{array}$ & $\begin{array}{c}60+\text { Minutes } \\
(\%)\end{array}$ \\
\hline Doctoral students & 17.6 & 31.4 & 29.4 & 19.6 \\
Master's students & 15.6 & 45.9 & 24.8 & 11.9 \\
Juniors and seniors & 26.8 & 45.3 & 21.1 & 4.4 \\
Freshmen and sophomores & 29.4 & 45.1 & 19.6 & 3.9 \\
\hline
\end{tabular}

to be visible and friendly to all CD-ROM users. This will perhaps increase the undergraduate user's willingness to ask questions of the library staff.

The final survey question relating to how patrons perceived the help available to them was, "Would you consider attending a fifty-minute instruction session on effective CD-ROM searching?" Fifty-six percent of survey respondents answered yes to this question. Pattee Library had been offering weekly fiftyminute sessions on effective use of BRS/After Dark, but these classes were generally difficult to teach as there was no way to predict how many people would show up or what subjects these patrons were researching. As CD-ROMs began to enter the library, the staff realized many patrons coming to the BRS classes also wanted to know about CDROMs. Beginning in the fall of 1990 , the library began to offer on a less frequent basis subject specific classes in which a librarian discusses all aspects of database searching relevant to a specific group: CDROMs, BRS/After Dark, and librarianmediated searches. These instruction sessions are promoted within specific colleges and departments in the hopes of attracting many participants. Librarians at Penn State also demonstrate CD-ROMs in bibliographic instruction (BI) sessions.
Presently, the Penn State Libraries do not have sufficient staff to offer fifty-minute classes solely on CD-ROM searching; however, librarians have begun to look at various options for user instruction.

Related to the questions of help were questions concerning the nature of the patrons' searches. Again, a series of questions on the survey (numbers 7-10 in the fall survey and numbers 8-11 in the spring survey) were analyzed. Table 7 shows the results of how long patrons took to search.

The majority of users took between fifteen to thirty minutes to search. Undergraduates took less time to search than other groups, and doctoral students took more time to search. These results tend to verify other results in the survey, as doctoral students used databases that would demand more search time to learn and use, e.g., ERIC or the MLA Bibliography, and undergraduates searched easier systems designed to retrieve a few references quickly, e.g., Readers' Guide or Business Periodicals Index. Table 8 shows number of references retrieved.

For the spring semester, the question was reworded for clarity, and a fifth choice was added; thus, the results must be looked at for each semester. Many users did find over 20 references in the fall and over 50 references in the spring,

TABLE 8

NUMBER OF REFERENCES RETRIEVED (TOTAL FOR EACH SEMESTER)

\begin{tabular}{lccccc}
\hline \multirow{3}{*}{ Fall } & $0-5$ & $6-10$ & $11-15$ & $20+$ & \\
\cline { 2 - 6 } & 53 & 34 & 39 & 120 & $50+$ \\
\cline { 2 - 6 } Spring & $0-5$ & $5-15$ & $15-25$ & $25-50$ & 65 \\
\hline
\end{tabular}


and of these, most users thought between $26 \%$ to $50 \%$ of these references would be useful. Regarding whether users were satisfied with their results, $56 \%$ of respondents marked either 1 (very satisfied) or 2 on the Likert scale for this question on the survey. However, since many patrons would not immediately know which of their references might be useful, these results should be considered with caution. One could hope that patrons did feel satisfied with their results, but to determine how satisfied patrons are with CDROM results, a different survey would need to be designed and administered as patrons looked for and found the material retrieved from the CD-ROM systems.

\section{The Reference Section also was interested to see if CD-ROM users were ignoring other sources of information.}

The results from the remaining questions on the survey (numbers 11-13 for the fall and 12-14 for the spring) are as follows. Over $86 \%$ of users from both semesters found the systems easy to use; approximately $48 \%$ of users, mostly doctoral students, planned their searches in advance; and an overwhelming $97 \%$ said they would use the systems again. The results indicating that these new electronic products are easy to use may be viewed positively. However, librarians can never know how correctly patrons may be using these systems. The Reference Section staff was also pleased that nearly half of the respondents did try to do some preliminary planning of their searches, but many patrons still sit down at these systems with no prior thought or planning as to how they will proceed. The Reference Section and other sections within the Penn State Libraries are still investigating ways to help patrons think about and plan their searches. Users need to be made aware that many of these products are more sophisticated tools than print reference sources and that proper planning will save them time and frustration.
While the main purpose of this survey was to determine both the characteristics of CD-ROM users and how users were interacting with the systems, the Reference Section also was interested to see if CD-ROM users were ignoring other sources of information. The reference librarians realized the CD-ROM systems would not replace reference sources, but would rather enhance the fine collection of print and microform sources already in the section. The Pennsylvania State University is a major research institution, and the reference collection has been built over time with great care and attention to serve all types of patrons at such an institution. Knowing the appeal of computers, the section feared patrons might begin to use the new CD-ROM technology and ignore the multitude of other sources available to them.

While it is difficult to determine on a fifteen question survey whether patrons did use other sources, the author did attempt to construct a question that might indicate whether users were looking at other sources. In the fall, the question read, "Do you plan to use traditional print sources in your research?" Although almost $70 \%$ of users in the fall said yes to this question with another $3 \%$ answering maybe, the question may have confused respondents. Some respondents did not answer this question and one person wrote, "What does this mean?" Therefore, the question was reworded in the spring and read, "Have you used or do you plan to use other sources in your research?" Eighty-eight percent responded yes. While these numbers can be interpreted positively, they should still be looked at with some suspicion. However this question was worded, it is impossible to determine how respondents read the question. Traditional sources obviously mean one thing to librarians but may mean something quite different to users, and other sources also could mean a variety of things: textbooks, nonreference monographs, lectures, or information from a professor. Pretesting of this question as well as follow-up interviews with survey respondents would have provided a 
much clearer picture of patrons' use of all types of reference material. Nonetheless, librarians in the section continue to teach traditional reference sources in BI classes and to make users aware of the variety of sources, both print and electronic, that are available in the Reference Section and other areas of the Penn State University Libraries. And if a busy day in the section is any clue, it is clear that patrons continue to use print sources in abundance.

\section{The majority of users took}

between 15 to 30 minutes to search.

Undergraduates took less time to

search than other groups, and

doctoral students took more time

to search.

As with many surveys, space was left for comments. The majority of patrons did not write comments, but of those who did most were interesting and insightful. Many comments were about the equipment: respondents wanted better printers, 31 /4-inch disc drives, and faster systems. Most academic libraries with CD-ROMs cannot always afford the best equipment. In the Reference Section at Pattee, most systems run on IBM PC/XTs with Hewlett Packard ink jet printers. Patrons commented on other aspects of the systems the library cannot change: Wilson systems show only one citation at a time; subject headings or terms are difficult to discern; more online help and prompts are wanted; and abstracts are desired on systems such as the Social Sciences Index. Again, libraries owning CD-ROM products can make suggestions to vendors, but vendors differ in their willingness and capability to change products. Many comments, however, specifically related to conditions or procedures that could be investigated and altered if possible. By far, the most prevalent comment concerned a desire for duplicate systems, especially for ERIC and PsycLIT. Users also commented that the sign-up procedure for these two systems was unfair. A few people also mentioned that the instruction sheets were confusing, and others said that they would like to have seminars or workshops on using CD-ROMs. One comment noted a need for more staff.

These comments are quite valuable for the Reference Section as well as for other sections of the Penn State Libraries system. Several librarians are investigating ways to improve our service. Seminars to introduce the basics of online searching, including CD-ROMs, BRS/After Dark, Knowledge Index (which was just added in the spring of 1991), and librarian-mediated searches are now offered every semester for patrons of different disciplines. A CD-ROM users group has been meeting to work on improving instruction sheets and making sure all areas have uniform instructions. Recently a CD-ROM task force completed a set of recommendations for the improvement of CD-ROM acquisitions and services. The libraries' administration has listened attentively to such reports and does try to respond to requests for more equipment and staff.

\section{CONCLUSION}

Overall, the Penn State experience with CD-ROMs has been a positive one for both library staff and users. While user surveys can never tell the whole story of how patrons are responding to a library service, they can provide valuable ideas about what does and does not work. The Penn State Libraries introduced CDROM products in 1986, and the librarians who planned and continue to monitor these systems had several hunches about how users would react to this new technology. For the most part, the two surveys conducted in the General Reference Section of Pattee Library proved these hunches to be true.

As the Penn State University Libraries move into the 1990s, electronic sources will continue to flourish as they will at other academic libraries. Already Penn State has taken the initiative with several electronic services. The libraries are a test site for the Electronic Bulletin Board produced by the Department of Com- 
merce. In the spring of 1991, the libraries added access to UnCover, a database of over 600,000 periodical citations produced by the Colorado Alliance of Research Libraries, CARL, and Knowledge Index, Dialog's version of BRS/After Dark. Dow Jones News Retrieval has been set up on a separate workstation in the CD-ROM area in General Reference. Plans are under way to allow access to remote databases and library catalogs through the Internet, and LIAS, Penn State's online catalog, will undergo a major upgrade in the fall of 1991 as Boolean and keyword searching are added. With this accomplished, commercial databases such as Medline will be mounted on LIAS with the help of grant money.

As these electronic systems continue to expand, many questions will arise about how to train and educate users on these systems. Many of the initial questions and hunches librarians had about users' reactions to CD-ROMs will be applicable. The Penn State Libraries will want to know who will be accessing all of these systems; how they will use the systems; what type of training these users will want; and what ideas these users have about improving service to the systems. While no one can predict the future of CD-ROM, the experience of CD-ROM users at Penn State has provided librarians here with valuable insight as to how users are responding to technology in the library. These experiences should also provide other academic libraries with answers and insight as we move into a decade of great change and challenge. The technology library is here, but our users' needs and desires must never be forgotten.

\section{REFERENCES AND NOTES}

1. See, for example, Nancy K. Herther, "CD-ROM [Compact Disc: Read Only Memory] Technology: A New Era for Information Storage and Retrieval?" Online 9:17-28 (Nov. 1985); David C. Miller, "Running with CD-ROM," American Libraries 17:754-6 (Nov. 1986); Christopher G. Pooley, "Silverplatter Brings CD-ROM to the Reference Desk," Database 9:40-42 (Aug. 1986); and Carol Tenopir, "Databases on CD-ROM," Library Journal 111:68-69 (Mar. 1, 1986).

2. Caroline Moore, "Survey of CD-ROM Users in the UK," Program 23:385-93 (Oct. 1989); Jenny Stocks, "CD-ROM Down Under: A Delphi Study of CD-ROM in Australian Academic and Special Libraries," Laserdisk Professional 3:18-22 (Jan. 1990).

3. See, for example, David Raitt and Ching-chih Chen, "Optical Products in European Libraries and Information Centres: Results of a Survey," in Proceedings of the 13th International Online Information Meeting, London, December 12-14,1989 (Oxford: Learned Information, 1989), p. 227-32; Raitt and Chen, "Use of Optical Products in Libraries and Information Centres in Western Europe," The Electronic Library 8:15-25 (Feb. 1990); Chen and Raitt, "Optical Products in American and European Libraries and Information Centers: Similarities, Differences, and Trends," Microcomputers for Information Management 7:1-23 (Mar. 1990); and Chen and Raitt, "How Optical Products Have Been Used in the U.S. and Western Europe," in National Online Meeting Proceedings-1990, New York, May 1-3, 1990, ed. Martha E. Williams (Medford, N.J.: Learned Information, 1990), p. 81-87.

4. Barbara A. Rapp and others, "Evaluating MEDLINE on CD-ROM: An Overview of Field Tests in Library and Clinical Settings," Online Review 14:172-86 (June 1990).

5. Anchalee Chamchuklin and Aung-Myint, "An Evaluation of CD-ROM MEDLINE Use in Thailand," Bulletin of the Medical Library Association 78:395-99; Beryl Glitz, "Testing the New Technology: MEDLINE on CD-ROM in an Academic Health Sciences Library," Special Libraries 79:28-33 (Winter 1988); Maureen Wong, Angella Lambrou, and Linda Ordogh, "A Survey on the Use of CD-ROM in Canadian Medical School Libraries," Laserdisk Professional 2:51-58 (Jan. 1989); Peter M. LePoer and Carol A. Mularski, "CD-ROM's Impact on Libraries and Users," Laserdisk Professional 2:39-45 (July 1989). 
6. L. Scott Rawnsley, "A Laserdisk for Law Students-IAC's LegalTrac Database," Database 9:25-30 (Dec. 1986); John J. Welsh, "Evaluation of CD-ROM Use in a Government Research Library," Laserdisk Professional 2:55-61 (Nov. 1989).

7. Carolyn Pope, "An Evaluation of ERIC on CD-ROM in a College Library," The Electronic Library 7:94-97 (Apr. 1989); Jean Reese, “CD-ROM Technology at Vanderbilt University: Impact on Library Staff and the Educational Community," Optical Information Systems 9:38-43 (Jan.-Feb. 1989).

8. Sten Wiksten, "Learning the Hard Way: A Public Library's Experience with CD-ROM," The Electronic Library 8:107-9 (Apr. 1990).

9. See, for example, Beth Juhl and Anita Lowry, "The CD-ROM 'Revolution' at Columbia: Year One," The Serials Librarian 17:69-80 (1990); Patricia Lynn and Karen Bacsanyi, "CD-ROMs: Instructional Methods and User Reactions," Reference Services Review 17:17-25 (Summer 1989); Kim Schultz and Kristine Salomon, "End Users Respond to CD-ROM," Library Journal 115:56-57 (Feb. 1, 1990); Howard Silver, "Managing a CDROM Installation ... a Case Study at Hahnemann University," Online 12:61-66 (March 1988); Ramona J. Steffey and Nikki Meyer, " Evaluating User Success and Satisfaction with CD-ROM," Laserdisk Professional 2:35-45 (Sept. 1989); and Terri Pedersen Summey, "CD-ROMs in the Library: User Evaluation of the Wilsondisc Indexes at Emporia State University," in The Best for the Patron, Proceedings of the Research Forum, Academic Library Section, Mountain Plains Library Association: Joint Conference, Mountain Plains Library Association, Utah Library Association, May 2-5, 1990, ed. Randy J. Olsen and Blaine $\mathrm{H}$. Hall (Emporia, Kans.: Emporia State Univ., 1990), p.89-99.

10. See, for example, Anne-Marie Belanger and Sandra D. Hoffman, "Factors Related to Frequency of Use of CD-ROM: A Study of ERIC in an Academic Library," College \& Research Libraries 51:153-62 (Mar. 1990); Marilyn M. Browning and Leslie M. Haas, "Is Business Periodicals Ondisc the Greatest Thing Since Sliced Bread?: A Cost Analysis and User Survey," CD-ROM Professional 4:37-41 (Jan. 1991); Somporn Puttapithakporn, "Interface Design and User Problems and Errors: A Case Study of Novice Searchers," $R Q$ 30:195-203 (Winter 1990); and Linda Stewart and Jan Olsen, "Compact Disk Databases: Are They Good for Users?" Online 12:48-52 (May 1988).

11. See, for example, Gillian Allen, "Patron Response to Bibliographic Databases on CD-ROM," RQ 29:103-10 (Fall 1989); Douglas J. Ernest and Holley R. Lange, "INFOTRAC and WILSONDISC: A Comparison of New Technologies," Reference Services Review 17:67-75 (Summer 1989); Charles Forrest, Karen Chapman, and Joyce Wright, "Periodical Indexing Ondisc: A Comparative Analysis of InfoTrac Use in Three Illinois Libraries," Reference Services Review 17:85-92; and John G. Jaffe, "For Undergrads: InfoTrac MAGAZINE INDEX Plus or WILSONDISC with Readers'Guide \& Humanities Index?" American Libraries 19:759-61 (Oct. 1988).

12. Carol Reese, "Manual Indexes Versus Computer-Aided Indexes: Comparing the Readers' Guide to Periodical Literature to InfoTrac II," RQ 27:384-89 (Spring 1988).

13. Gillian Allen, "CD-ROM Training: What Do the Patrons Want?," RQ 30:88-93 (Fall 1990); Gillian Allen, "Database Selection by Patrons Using CD-ROM," College \& Research Libraries 51:69-75 (Jan. 1990).

14. Susan K. Charles and Katherine E. Clark, "Enhancing CD-ROM Searches with Online Updates: An Examination of End-User Needs, Strategies, and Problems," College \& Research Libraries 51:321-28 (July 1990).

15. Bruce Bonta and Sally Kalin, "CD-ROM Implementation: A Reference Staff Takes Charge," Reference Services Review 17:7-11+ (Summer 1989). 